\title{
«НЕМОЛОЧНОЕ МОЛОКО॥: ОБЗОР СЫРЬЯ И ТЕХНОЛОГИЙ
}

\author{
Е. Ю. Егорова
}

Статья посвящена вопросам пищевого использования возобновляемых ресурсов белоксодержащего сырья. На примере международного и отечественного продовольственного рынка прослежены общие тенденции развития относительно нового сектора молочной отрасли - «растительного молока», рассмотрены наиболее популярные торговые марки и чаще всего используемые группы и виды белоксодержащего растительного сырья (бобовые, злаковые, орехоплодные). Охарактеризованы основные и дополнительные компоненты рецептурного состава растительного молока и принятая классификация этого напитка по природе сырья; проанализированы преимущества и недостатки пищевой ценности растительного молока разных видов и основные требования к его коллоидному состоянию. Перечислены основные стадии технологии производства растительного молока, с акцентом на операции и технологические приемы, обеспечивающие физико-химическую стабильность коллоидной системы напитка и его пригодность для промышленных способов стерилизации с иелью обеспечения длительного срока годности. Оценен вклад различных технологических фракторов в формирование качества растительного молока. Отмечена взаимосвязь между фрракционным составом белков сырья - в качестве характеристики потенциальной пригодности для производства растительного молока - и важнейшими технологическими и потребительскими свойствами готового напитка, включая его пищевую ценность.

Ключевые слова: растительное молоко, «немолочное молоко», соевое молоко, обзор рынка, ассортимент, пищевая ценность, технология, сырье, коллоидная стабильность, белок.

\section{РЫНОК РАСТИТЕЛЬНОГО МОЛОКА И СЫРЬЯ ДЛЯ ЕГО ПРОИЗВОДСТВА}

Развитие современного продовольственного рынка сопровождается непрерывным расширением спектра промышленной переработки протеинового сырья и поиском новых, потенциально пригодных для этого возобновляемых сырьевых ресурсов.

В целом, по прогнозам аналитиков международного рынка, к 2020 году объем продаж растительных белков может достичь 10,12 млрд. \$ [1]. В качестве источников протеинов на потребительском рынке сегодня представлены соевая, рисовая, гороховая, конопляная, ореховая и другие виды муки, содержащие от 35 до 85 \% белка [2].

Ведущую роль в развитии рынка протеинов играет производство заменителей мясных и молочных продуктов, включая напитки [3]. Отдельного внимания заслуживает сектор так называемого Non-Dairy Milk («немолочное молоко»), активное развитие которого связывается как с индивидуальной непереносимостью лактозы и/или молочного казеина у все большего числа потребителей, так и с активной пропагандой вегетарианства и физиологической предпочтительности потребления растительного белка, особенно в геродиетическом питании [4-8]. В свое время этот продукт был придуман в качестве альтернативы животному молоку, в том числе для решения проблемы дефицита белка в экономически неразвитых странах, но сегодня становится все более популярным. Кроме непосредственного потребления в пищу, растительное молоко используется и в качестве основы для производства немолочных пробиотических и других продуктов традиционно молочного сектора - сливок, йогуртов, сыров, мороженого и прочих $[9,10]$.

Наиболее динамично рынок растительного молока развивается в США, где, по данным [4], в 2016 году доля немолочного молока составляла 8 \% объема рынка всех молочных продуктов и, по прогнозам аналитиков Global Market Research, к концу 2018 года стоимостной эквивалент сегмента должен достичь 4,5 млрд. \$.

В 2017 году был зафиксирован очередной виток роста рынка Non-Dairy Milk и, как предполагают аналитики, в ближайшие годы динамика роста, в целом, будет сохраняться [11].

Считается, что темпы роста рассматриваемого сегмента мирового рынка в США составляют около 15,5 \% ежегодно, в Европе около 7 \%. С учетом этих темпов ожидается, что уже к концу 2018 году сегмент «немолочного молока» на мировом рынке будет занимать 14 млрд. \$[6], к 2020 году достигнет 


\section{Е. Ю. ЕГОРОВА}

19,5 млрд. \$ [4], а к 2022 году только в Европейских странах будет эквивалентен 9,5 млрд. $\$[12]$.

В последние годы растительное молоко начало набирать популярность и в России. В таблице 1 приведен ряд популярных наименований растительного молока, предлагаемого производителями на собственных сайтах и сайтах интернет-магазинов, в том числе российских.

Одно из первых (исторически) видов растительного молока - соевое - постепенно сдает свои позиции [13]. В значительной степени это связано с недостаточно высокими органолептическими характеристиками соевого молока [6, 14-16] и насыщением сырьевого рынка продуктами переработки генетически модифицированных сортотипов сои, что снижает доверие потребителей к этому продукту. В связи с этим потребительский рынок и производители переориентируются на альтернативные виды сырья, позволяющего в промышленных масштабах производить другие аналоги молока - миндальное $[4,17]$, из зерна злаковых и масличных культур [6, 18], кокосового и грецкого ореха, арахиса [19], фундука, кешью, из семян бахчевых культур [20, 21] либо смешанного состава - как рисово-миндальное и рисово-кокосовое (Riso Scotti, Италия), соевокукурузное, соево-кокосовое, соевое с экстрактом чуфы [14, 22], мультизерновые [6].

Если рассматривать общемировые тенденции развития сектора Non-Dairy Milk, то следует отметить, что лишь в Австралии пока не особо развит интерес к рассматриваемому сегменту и сохраняются устойчивые рыночные позиции протеинов, молока и молочных напитков животного происхождения [23].

В натуральном и стоимостном выражении, по объемам продаж в существующем ассортименте растительного молока еще доминирует соевое [24], но покупательский спрос на другие «молочные» напитки из растительного сырья неуклонно растет. Становятся все более популярны растительные аналоги молока, произведенные из орехов и злаков, поскольку они обладают более приемлемым и даже приятным вкусом и запахом по сравнению с соевым молоком [17]. Как следствие, буквально за несколько последних лет на 2-е и 3-е места в структуре продаж этих напитков и в США, и в странах Европы вышли миндальное и рисовое молоко [4, 24].

Классификация, в основу которой положен вид белоксодержащего сырья, предлагает выделение пяти групп таких напитков:

- из злаковых - овсяное, рисовое, кукурузное, полбяное;
- из зернобобовых - соевое, арахисовое, люпиновое, из вигны и мукуны;

- из орехов - миндальное, кокосовое, фристашковое, кедровое, из грецкого ореха и фундука;

- из масличных семян - кунжутное, льняное, конопляное, подсолнечное;

- из псевдо-зерновых культур - амарантовое, из киноа, тефра и т. д. [6].

Практически каждый производитель специализируется на выпуске собственной ассортиментной линейки растительного молока и сливок, нередко - сразу из нескольких видов сырья. С этим связано многообразие представленных на потребительском рынке наименований. Например, уже достаточно хорошо известные на мировом продовольственном рынке бренды овсяного молока - это Oatly (Швеция), Pure Harvest (Австралия), Alpro (Великобритания), Bio Avena Drink (Италия), Simpli (Финляндия), Vitasoy (Гон Конг), Pacific (США), миндального - Silk, Almond Breeze Hiland, 365 и Pacific (США), Alpro (Великобритания), Pure Harvest (Австралия), рисового - DREAM и Kirkland (США), BIO RICE DRINK и Ora Si (Италия), и т. д.

В России продажи растительных аналогов молока составляют примерно $1 \%$, что в 2017 году в денежном выражении составило 461,4 млн. руб.; самые популярные позиции на сегодня - это соевое, миндальное и кокосовое молоко [12].

\section{ТЕХНОЛОГИИ ПРОИЗВОДСТВА РАСТИТЕЛЬНОГО МОЛОКА}

Прототипами существующих технологий растительного молока можно считать способы приготовления орчаты и кунны - прохладительных напитков из орехов или злаков и подслащенной воды. Орчата (Horchata) - рисовая, миндальная, кунжутная, из чуфы - в некоторых странах популярна и сейчас [25].

При разработке современных технологий производители ориентируются преимущественно на органолептические показатели качества коровьего молока. Немаловажной характеристикой считается также уровень содержания в напитке белков, хотя фрактически в промышленном растительном молоке содержание белка редко превышает 1-1,5 \% (см. таблицу 1).

Коровье молоко - это особым образом структурированная коллоидная система эмульсия, пищевая ценность и технологические свойства которой обеспечиваются составом, соотношением и свойствами белков, жиров и углеводов. 
Таблица 1 - Ассортимент молока и сливок из растительного сырья

\begin{tabular}{|c|c|c|c|c|c|c|c|}
\hline \multirow{2}{*}{$\begin{array}{c}\text { Наименование } \\
\text { продукта, } \\
\text { производи- } \\
\text { тель }\end{array}$} & \multicolumn{2}{|c|}{ Состав сырья } & \multicolumn{4}{|c|}{ Химический состав, в 100 мл } & \multirow[b]{2}{*}{$\begin{array}{l}\text { ЭЦ, } \\
\text { кДж }\end{array}$} \\
\hline & $\begin{array}{l}\text { основного и до- } \\
\text { полнительного }\end{array}$ & $\begin{array}{c}\text { вспомога- } \\
\text { тельного }\end{array}$ & белки & жиры & $\begin{array}{l}\text { угле- } \\
\text { воды }\end{array}$ & $\begin{array}{c}\text { пище- } \\
\text { вые } \\
\text { волокна }\end{array}$ & \\
\hline 1 & 2 & 3 & 4 & 5 & 6 & 7 & 8 \\
\hline $\begin{array}{l}\text { 1. Silk Soy Milk } \\
\text { Original, США, } \\
\text { Groupe } \\
\text { Danone }\end{array}$ & $\begin{array}{c}\text { вода, соевые } \\
\text { бобы, тростнико- } \\
\text { вый сахар, } \\
\text { морская соль, } \\
\text { СаСО } \\
\text { витамины } \\
\text { В, А, } D_{2}, B_{2}, B_{12} \\
\end{array}$ & $\begin{array}{c}\text { геллановая } \\
\text { камедь, } \\
\text { натуральный } \\
\text { ароматизатор }\end{array}$ & 2,5 & 1,5 & 3,7 & 0,4 & 160 \\
\hline $\begin{array}{l}\text { 2. Oatly! Oat } \\
\text { Milk Barista } \\
\text { Edition, } \\
\text { Швеция, } \\
\text { Oatly Inc. }\end{array}$ & $\begin{array}{c}\text { вода, овес, } \\
\text { рапсовое масло, } \\
\text { йодированная } \\
\text { соль, СаCО } \\
\text { витамины } \\
\mathrm{D}_{2}, \mathrm{~B}_{2}, \mathrm{~B}_{12}\end{array}$ & $\begin{array}{c}\text { ортофросфрат } \\
\text { калия двузаме- } \\
\text { щенный, орто- } \\
\text { фоосфат кальция } \\
\text { трехзамещен- } \\
\text { ный }\end{array}$ & 1,0 & 3,0 & 5,7 & 0,8 & 230 \\
\hline $\begin{array}{l}\text { 3. Aroy-D } \\
\text { Coconut Milk, } \\
\text { Таиланд, Thai } \\
\text { Agri Foods } \\
\text { Public Com- } \\
\text { pany Limited }\end{array}$ & $\begin{array}{l}\text { мякоть кокосо- } \\
\text { вого ореха, вода }\end{array}$ & Нет информации & 1,5 & 19,0 & 2,0 & 0 & 760 \\
\hline $\begin{array}{l}\text { 4. Blue Dia- } \\
\text { mond Almond } \\
\text { Breeze Almond- } \\
\text { milk, CШA, } \\
\text { Blue Diamond } \\
\text { Almonds }\end{array}$ & $\begin{array}{c}\text { вода, миндаль, } \\
\text { морская соль, } \\
\mathrm{CaCO}_{3}, \text { вита- } \\
\text { мины A, D2, E }\end{array}$ & $\begin{array}{c}\text { крахмал та- } \\
\text { пиоки, цитрат ка- } \\
\text { лия, каррагинан, } \\
\text { лецитин соевый }\end{array}$ & 0,4 & 1,0 & 0,4 & $\begin{array}{c}\text { менее } \\
0,4\end{array}$ & 55 \\
\hline $\begin{array}{l}\text { 5. Good Karma } \\
\text { Flaxmilk Va- } \\
\text { nilla, CШA, } \\
\text { Good Karma } \\
\text { Foods Inc. }\end{array}$ & $\begin{array}{c}\text { вода, льняное } \\
\text { масло, изолят } \\
\text { белка гороха, } \\
\text { тростниковый са- } \\
\text { хар, морская } \\
\text { соль, витамины } \\
\text { A, } D_{2}, B_{12}\end{array}$ & $\begin{array}{c}\text { крахмал та- } \\
\text { пиоки, лецитин } \\
\text { подсолнечный, } \\
\text { геллановая } \\
\text { и ксантановая } \\
\text { камедь, } \\
\text { экстракт ванили }\end{array}$ & 3,5 & 1,5 & 5,0 & 0 & 200 \\
\hline $\begin{array}{l}\text { 6. Suzie's } \\
\text { Quinoamilk, } \\
\text { CШA, Good } \\
\text { Groceries } \\
\text { Company Inc. }\end{array}$ & $\begin{array}{c}\text { вода, киноа, } \\
\text { морская соль, } \\
\mathrm{CaCO}_{3}, \\
\text { витамины } \mathrm{A}, \mathrm{D}_{2}, \mathrm{E}\end{array}$ & $\begin{array}{c}\text { геллановая } \\
\text { камедь, } \\
\text { натуральный } \\
\text { ароматизатор } \\
\text { ванили } \\
\end{array}$ & 0,4 & 0 & 3,4 & 0 & 65 \\
\hline $\begin{array}{l}\text { 7. Pacific } \\
\text { Hazelnut Non- } \\
\text { Dairy Beverage } \\
\text { Original, СШA, } \\
\text { Pacific Food }\end{array}$ & $\begin{array}{c}\text { вода, молотый жа- } \\
\text { реный фундук, ко- } \\
\text { ричневый } \\
\text { рисовый сахар, } \\
\text { морская соль } \\
\end{array}$ & $\begin{array}{c}\text { ортофоосфат каль- } \\
\text { ция трехзамещен- } \\
\text { ный, геллановая } \\
\text { камедь, карраги- } \\
\text { нан }\end{array}$ & 0,8 & 1,6 & 7,5 & 0,4 & 203 \\
\hline $\begin{array}{l}\text { 8. RICE } \\
\text { DREAM Rice } \\
\text { drink, CШA, } \\
\text { Hain Celestial } \\
\text { Group Inc. }\end{array}$ & $\begin{array}{c}\text { вода, коричневый } \\
\text { рис, масло кано- } \\
\text { лы и/или сафло- } \\
\text { ровое масло, } \\
\text { и/или подсолнеч- } \\
\text { ное масло, } \\
\text { морская соль, ви- } \\
\text { тамины } \\
\text { A, } D_{2}, B_{12}\end{array}$ & $\begin{array}{c}\text { ортофосфрат } \\
\text { кальция трехза- } \\
\text { мещенный }\end{array}$ & 0,4 & 1,0 & 9,6 & 0 & 207 \\
\hline
\end{tabular}




\section{Е. Ю. ЕГОРОВА}

Продолжение таблицы 1

\begin{tabular}{|c|c|c|c|c|c|c|c|}
\hline 1 & 2 & 3 & 4 & 5 & 6 & 7 & 8 \\
\hline $\begin{array}{l}\text { 9. So Delicious } \\
\text { Dairy Free } \\
\text { Cashewmilk, } \\
\text { США, So Deli- } \\
\text { cious Dairy } \\
\text { Free Company }\end{array}$ & $\begin{array}{c}\text { вода, кешью, } \\
\text { масло канолы, } \\
\text { морская соль, } \\
\text { витамины } \\
\text { А, } D_{2}, B_{c}, B_{12} ; \\
\text { селен, цинк }\end{array}$ & $\begin{array}{l}\text { ортофосфраты каль- } \\
\text { ция и магния, ка- } \\
\text { медь рожкового де- } \\
\text { рева, геллановая и } \\
\text { гуаровая камедь }\end{array}$ & 0 & 1,5 & 0,4 & 0 & 62 \\
\hline $\begin{array}{l}\text { 10. Living Har- } \\
\text { vest Tempt } \\
\text { Hemp Milk, } \\
\text { CШA, Living } \\
\text { Harvest Inc. }\end{array}$ & $\begin{array}{c}\text { вода, семена ко- } \\
\text { нопли, } \\
\text { морская соль, } \\
\text { витамины } \\
\mathrm{A}, \mathrm{D}_{2}, \mathrm{~B}_{2}, \mathrm{~B}_{12}\end{array}$ & $\begin{array}{c}\text { ортофросфрат каль- } \\
\text { ция трехзамещен- } \\
\text { ный, каррагинан, } \\
\text { лецитин подсол- } \\
\text { нечный }\end{array}$ & 0,8 & 2,5 & 3,7 & 0 & 170 \\
\hline $\begin{array}{l}\text { 11. BIO RICE } \\
\text { DRINK natural, } \\
\text { Италия, The } \\
\text { Bridge Bio }\end{array}$ & $\begin{array}{c}\text { вода, рис, } \\
\text { подсолнечное } \\
\text { и сафлоровое } \\
\text { масло, } \\
\text { морская соль }\end{array}$ & Нет информации & $\begin{array}{c}\text { менее } \\
0,5\end{array}$ & 1,3 & 11,5 & - & 250 \\
\hline $\begin{array}{l}\text { 12. Alpro Al- } \\
\text { mond Unsweet- } \\
\text { ened, Велико- } \\
\text { британия, } \\
\text { Alpro }\end{array}$ & $\begin{array}{l}\text { вода, миндаль, } \\
\text { сахар, фрук- } \\
\text { тоза, СаСО } \\
\text { морская соль }\end{array}$ & $\begin{array}{c}\text { ортофоосфат калия } \\
\text { трехзамещенный, } \\
\text { геллановая и гуаро- } \\
\text { вая камедь, эмуль-га- } \\
\text { тор лецитин подсол- } \\
\text { нечный, регулятор } \\
\text { кислотности, } \\
\text { ароматизатор }\end{array}$ & 0,5 & 1,1 & 0 & 0,4 & 52 \\
\hline $\begin{array}{l}\text { 13. Alpro Cui- } \\
\text { sine Soya, } \\
\text { Велико-брита- } \\
\text { ния, } \\
\text { Alpro }\end{array}$ & $\begin{array}{c}\text { вода, } \\
\text { очищенные } \\
\text { соевые бобы, } \\
\text { масло подсол- } \\
\text { нечное, сахар, } \\
\text { морская соль }\end{array}$ & $\begin{array}{c}\text { эмульгатор } \\
\text { (эфиры сахарозы } \\
\text { и жирных кислот), } \\
\text { ксантановая и гуа- } \\
\text { ровая камедь, кар- } \\
\text { рагинан, } \\
\text { ароматизатор } \\
\end{array}$ & 2,0 & 15,0 & 1,2 & 0,3 & 612 \\
\hline $\begin{array}{l}\text { 14. Califia } \\
\text { Farms Pure Al- } \\
\text { mondmilk, } \\
\text { CШA, Buy } \\
\text { Califia Farms }\end{array}$ & $\begin{array}{c}\text { вода, миндаль, } \\
\text { тростниковый са- } \\
\text { хар, морская } \\
\text { соль, витамины } \\
\mathrm{A}, \mathrm{E}, \mathrm{D}_{2}, \mathrm{~B}_{2}, \mathrm{~B}_{12} \\
\text { цинк, } \mathrm{CaCO}_{3} \\
\end{array}$ & $\begin{array}{c}\text { цитрат калия, } \\
\text { эмульгатор } \\
\text { лецитин } \\
\text { подсолнечный, } \\
\text { ароматизатор }\end{array}$ & 0,4 & 1,7 & 2,1 & 0,4 & 110 \\
\hline $\begin{array}{l}\text { 15. Simple } \\
\text { Truth Vanilla } \\
\text { Almondmilk, } \\
\text { СШA, The } \\
\text { Kroger Co. }\end{array}$ & $\begin{array}{c}\text { вода, миндаль, } \\
\text { тростниковый са- } \\
\text { харный сироп, } \\
\text { морская соль, ви- } \\
\text { тамины } \\
\mathrm{A}, \mathrm{D}_{2}, \mathrm{E}\end{array}$ & \begin{tabular}{|c|} 
ортофоссфат каль- \\
ция трехзамещен- \\
ный, ортофосфат \\
калия двухзамещен- \\
ный, геллановая и \\
ксантановая ка- \\
медь, эмульгатор \\
лецитин подсолнеч- \\
ный, \\
ароматизатор \\
\end{tabular} & 1,0 & 2,5 & 15,0 & 1,0 & 370 \\
\hline $\begin{array}{l}\text { 16. Veggemo } \\
\text { Veggie based } \\
\text { non dairy drink } \\
\text { original, Колум- } \\
\text { бия, Global } \\
\text { Gardens Group }\end{array}$ & $\begin{array}{c}\text { вода, протеин го- } \\
\text { роха, крахмал та- } \\
\text { пиоки и картофе- } \\
\text { ля, тростниковый } \\
\text { сахар, подсол- } \\
\text { нечное масло, } \\
\text { морская соль, ви- } \\
\text { тамины } \mathrm{A}, \mathrm{D}_{2}, \mathrm{~B}_{2}, \\
\mathrm{~B}_{\mathrm{c}}, \mathrm{B}_{12}, \text { цинк }\end{array}$ & $\begin{array}{c}\text { ортофоссрат } \\
\text { кальция трехзаме- } \\
\text { щенный, геллано- } \\
\text { вая камедь, } \\
\text { ароматизатор }\end{array}$ & 6,0 & 2,5 & 7,0 & 2,0 & 330 \\
\hline
\end{tabular}


В отличие от коровьего молока, растительное представляет собой суспендированную эмульсию, коллоидная стабильность которой обусловлена не только свойствами и составом названных компонентов, но и гранулометрическими характеристиками взвешенных частиц.

Используемые способы получения растительного молока основаны преимущественно на извлечении из используемого сырья водо- и солерастворимых фрракций белков, отличающихся более низкой молекулярной массой по сравнению с остальными белками, а соответственно, и более легкой и полной усвояемостью. Эти фракции обеспечивают коллоидную стабильность напитков и являются преобладающими в составе белков зернобобовых и масличных семян (таблица 2).

Непосредственное растворение измельченного растительного сырья не обеспечивают нужные технологические свойства рассматриваемого напитка. Одновременно с растворением белков, из сырья экстрагируются водорастворимые углеводы, минеральные соли и некоторые другие растворимые компоненты, переходят в воду набухшие мельчайшие частицы растительного сырья. Седиментация взвешенных частиц является одной из основных причин нестабильности напитков в хранении, поэтому для получения стойкой коллоидной системы необходим правильный подбор метода воздействия. Выбор технологических параметров может быть также связан с необходимостью блокировки или разрушения антипитательных компонентов: ингибиторов протеаз, лектинов (как, например, при использовании зерна бобовых или некоторых масличных культур), специфических алкалоидов, сапонинов (например, при переработке клубеньков чуфы) либо дубильных веществ, способных вызвать осаждение белка при получении напитка [25].

Классическим способом измельчения частиц сырья с целью придания однородной эмульсионной консистенции соевому и арахисовому молоку является использование коллоидной мельницы, когда гомогенизация суспензии достигается так называемым мокрым помолом [26]. Кроме этого, растительное молоко гомогенизируют в условиях сверхвысокого давления [27-29], ультразвуковой кавитации [30, 31] либо сочетанием этих эффектов [32].

При использовании сверхвысокого давления основной целью является гомогенизация суспензии, полученной путем предварительного перетирания растительного сырья в воде. В случае применения ультразвука одновременно достигаются экстрагирование и диспергирование компонентов растительного сырья, за более короткое время с тем же результатом: получение стойкой суспендированной эмульсии.

Гомогенизация в условиях обработки ультразвуком осуществляется при частоте 20-30 кГц, при этом набухшие глобулы сырья разрушаются до частиц размерами 0,52,0 мкм [31]. Генерирование ультразвуковой кавитации способствует не только эффеектиному переходу в экстракт сухих веществ растительного сырья, но и получению этого экстракта в виде высококачественной, устойчивой, практически монодисперсной эмульсии, благодаря переходу белков и липидов сырья под действием акустических колебаний в растворимое или диспергированное состояние и дополнительному диспергированию при этом жировых капель [33]. Подобный эффрект дает введение в полученную эмульсию лецитина в сочетании с гомогенизацией в условиях сверхвысокого давления [29]. Доминирующими фракторами из числа формирующих свойства получаемых эмульсий являются мощность ультразвука и продолжительность обработки [33], для разрушения жировых капель более эффективно повышение мощности [6].

Вне зависимости от принятого способа гомогенизации, растительные аналоги сохраняют в своем составе достаточно крупные частицы. Частицы суспендированных эмульсий растительного молока имеют разбег значений от 0,55 мкм (соя) до 2,08 мкм (киноа), в то время как средний размер мицелл казеина коровьего молока составляет 0,52 мкм [34, 35]. Это обусловливает нестабильность крупных частиц в системе и возможность их отделения центрифугированием, что эффективно применяется в производственной практике.

Вариации в технологическом оформлении производства молока из сои и других бобовых определяются значениями следующих параметров:

- глубина и вид обработки зерна перед измельчением;

- степень измельчения зерна во время экстракции;

- рН экстрагента, гидромодуль;

- продолжительность и температура экстракции;

- способ и продолжительность гомогенизации полученной суспензии [36].

Для устранения бобового вкуса, вызванного повышенным содержанием в зерне сои серосодержащих соединений и коротко- 


\section{Е. Ю. ЕГОРОВА}

Таблица 2 - Фракционный состав белков некоторых видов растительного сырья, используемого и имеющего потенциал для производства растительного молока

\begin{tabular}{|c|c|c|c|c|}
\hline \multirow[t]{2}{*}{ Вид сырья } & \multicolumn{4}{|c|}{ Содержание фрракции белков, \% от суммы белков } \\
\hline & альбумины & глобулины & глютелины & проламины \\
\hline \multicolumn{5}{|l|}{ Зернобобовые: } \\
\hline Соя, зерно [37] & 68,5 & 22,1 & 9,4 & нет данных \\
\hline Горох, зерно [37] & 39,8 & 54,6 & 5,6 & нет данных \\
\hline Нут, зерно [37] & 50,1 & 41,6 & 8,3 & нет данных \\
\hline \multicolumn{5}{|l|}{ Зерновые: } \\
\hline Овес, зерно [38] & 7,8 & 32,6 & $31,8-51,8$ & $11,4-16,2$ \\
\hline Рис, зерно $[39,40]$ & $9-10$ & $6-10$ & $65-75$ & $4-5$ \\
\hline Кукуруза, зерно [41] & $9,6-10,0$ & $4,7-5,0$ & $30,0-40,3$ & $29,9-40,0$ \\
\hline \multicolumn{5}{|l|}{ Масличные: } \\
\hline Лен, семена [42] & 35,2 & 26,7 & 23,7 & 14,4 \\
\hline Амарант, семена [43] & $50,5-57,0$ & $17,0-25,9$ & $9,1-15,4$ & $3,6-7,5$ \\
\hline Тыква, семена [44] & $25,2-27,2$ & $42,8-48,3$ & $19,3-21,8$ & следы \\
\hline \multicolumn{5}{|l|}{ Орехи: } \\
\hline Миндаль, орехи [45] & $8,0-19,0$ & $71,3-83,8$ & $5,4-11,9$ & отсутствуют \\
\hline Фундук, орехи [46] & 76,1 & 21,1 & 2,5 & нет данных \\
\hline Грецкий орех, орехи [46] & 91,2 & 2,1 & 6,6 & нет данных \\
\hline
\end{tabular}

цепочечных жирных кислот, используются такие технологические приемы, как предварительное вымачивание зерна сои в щелочных растворах или разбавленном спирте [14], бланширование перед измельчением в кипящей воде или обжаривание (снижает также активность фитиновой кислоты, липоксигеназы и трипсина - на 25-50 \% [47]), обработку перегретым паром до $120-160^{\circ} \mathrm{C}$ [26], использование для получения «молока» проросших семян или изолятов соевого белка, мокрый размол в подкисленной воде, купажирование сырого «молока» из сои (перед завершающей обработкой) с «молоком» из злаков или орехов $[6,14,15]$.

Технологические операции пропаривания (или обжарки) и замачивания в слабощелочных растворах применяются при получении молока из всех видов зернобобовых и многих видов орехов. Эти операции позволяют повысить эффрективность экстракции белка и сухих веществ в целом, повысить коллоидную стабильность полученных эмульсий.

При нейтральных значениях $\mathrm{pH}$ полученных белковых эмульсий для их стабилизации дополнительно могут использоваться каррагинан и камеди, при кислых рН (менее 4,6) - пектины [6].

Ореховое молоко и молоко из семян масличных культур отличается от продукции из злаковых и зернобобовых более высоким содержанием липидов, экстрагируемых из исходного сырья в ходе технологической обработки и обусловливающих более высокую кол- лоидную стабильность напитка за счет эмульгирующих свойств ди- и моноглицеридов естественных эмульгаторов-загустителей [33].

Основным «минусом» переработки злаков в растительное молоко является высокое содержание крахмала в исходном сырье. При нагревании такое молоко может желироваться [25], при более длительной и высокотемпературной обработке структура коллоидной системы начинает разрушаться.

Преимущественным способом предотвращения гелеобразования в процессе термической обработки является ферментативный гидролиз. Овсяное молоко получают с применением амилаз $[6,48]$, соевое - с использованием $\alpha$-галактозидазы, позволяющей снизить в напитке содержание олигосахаридов [49].

Одним из основных факторов, влияющих на формирование качества растительного молока, является температура [50]. При получении аналогов молока из зернобобовых применение ультравысоких температур (УВТ) позволяет инактивировать трипсин [47], однако применение таких режимов на стадиях бланширования и обжарки влияет на фракционный состав белков, снижая их растворимость $[18,51]$. При получении напитков из злаков, сохраняющих в своем составе определенное количество крахмала, это ведет к повышению вязкости и желированию. Для такого растительного молока могут не подойти условия тепловой стерилизации, общепринятые в молочной отрасли и производстве безалкогольных напитков. 
Основной «удар» термической обработки (пастеризации или стерилизации) приходится на белки и липиды, с одной стороны - обусловливающих пищевую ценность растительного молока, с другой - обеспечивающих природу эмульсии. Кроме того, что нагрев сопровождается снижением растворимости и, соответственно, эмульгирующей способности белков, он провоцирует начало окислительных процессов ПНЖК и фоссфолипидов.

Вместе с тем, стерилизующая обработка необходима для обеспечения безопасности и микробиологической стабильности напитков в процессе хранения. Для напитков, выдерживающих термическую обработку (например, соевое молоко), завершающими стадиями промышленных технологий получения растительного молока являются стерилизация $\left(120^{\circ} \mathrm{C}\right.$, 15-20 минут) или УВТ $\left(135-150{ }^{\circ} \mathrm{C}\right.$, до 30 с.) стабилизированных эмульсий, с последующим охлаждением, повторной гомогенизацией и розливом в потребительскую упаковку в асептических условиях.

Для остальных напитков в качестве альтернативы тепловой стерилизации рассматриваются обработка в условиях сверхвысокого давления и пульсационная обработка в электрическом поле [6]. Оба метода считаются достаточно эфффективными в плане уничтожения микрофлоры и дают еще более глубокое измельчение суспендированных частиц обрабатываемой среды. Современные исследования, направленные на оценку эффрективности этих методов в технологии производства растительного молока, ориентированы на изучение взаимосвязи параметров обработки со сроком годности, коллоидной стабильностью, пищевой ценностью и, в том числе, органолептикой получаемого молока.

Для решения задачи продления сроков годности растительного молока одновременно изучаются условия восстановления порошков, полученных распылительной сушкой белковых эмульсий, полученных выше описанными способами [20].

\section{ПИЩЕВАЯ ЦЕННОСТЬ РАСТИТЕЛЬНОГО МОЛОКА}

Как правило, большинство коммерческих наименований растительного молока, сливок и молочных напитков обладает достаточно низким либо очень низким содержанием белка - (от 1-1,2...1,5 \% до менее 0,5 \%). К слову, именно низкое содержание белка и его неполноценность по сравнению с белками животного происхождения являются ведущей причиной запрета законодательства европейских стран на использование слова «молоко» в отношении к напиткам-аналогам, полученным из сырья растительного происхождения [52].

Только соевое молоко характеризуется содержанием белка, относительно сопоставимым по уровню с коровьим молоком [35], однако по аминокислотному составу более полноценными считаются белки арахиса [5]. Из злаковых относительно более ценным можно считать овсяное молоко, как по аминокислотному составу белков [53], так и за наличие ßглюкана [54], из масличного наибольшего интереса вызывают кунжутное и льняное - в связи с наличием в сырье сразу нескольких компонентов-антиоксидантов [55].

В растительном молоке выражен десрицит кальция и витамина E, поэтому большинство реализуемых наименований растительного молока перед окончательной гомогенизацией обогащается витаминно-минеральными премиксами, в связи с чем эти напитки рассматриваются также в сегменте функциональных [56, 24]. Но даже не обогащенное растительное молоко позиционируется как источник определенных физиологически функциональных компонентов, например: соевое - полиненасыщенных жирных кислот, изофлавонов и фитостеринов, арахисовое - полифенольных соединений, рисовое - фитостеринов, овсяное - ß-глюкана, кунжутное - лигнанов, миндальное - токоферолов и арабинозы, и т. д.

К дополнительным диетически ценным свойствам практически любого вида растительного молока можно отнести повышенное относительное содержание в составе белков аминокислоты аргинина, одной из физиологических функций которой считается стимуляция секреции гормонов, регулирующих выработку инсулина и чувствительность к нему организма [57]. Это оправдывает рекомендации потребления растительного молока предрасположенным к сахарному диабету.

Несмотря на наличие у растительного молока некоторых безусловных достоинств, определяющих возможность его использования в диетическом рационе питания, есть и существенные недостатки. Так, консистенция и вкусовые качества «молока», получаемого из разных видов растительного сырья, существенно различаются и многие виды уступают по вкусу охлажденному коровьему молоку. Наиболее часто упоминаемым недостатком соевого молока считается наличие у него специфического бобового привкуса.

Наличие взвешенных частиц в растительном молоке сопровождается их отложением на стенках потребительской упаковки 


\section{Е. Ю. ЕГОРОВА}

при хранении напитка, особенно при повышенном содержании сухих веществ (при том, что по сумме сухих веществ любое растительное молоко существенно уступает коровьему). Это же указывается в качестве причины таких дефектов растительного молока, как меловой или песочный привкус [6]. При очень низком содержании жира (порядка $1 \%$ и ниже) у растительного молока нет характерной сладости и «бархатистости» во фрлейворе.

Если коровье молоко не могут пить люди с непереносимостью лактозы, то растительное молоко, особенно молоко из бобовых и орехов, может вызывать пищевую аллергию, вплоть до анафилактического шока. Аллергеном, как в сое, так и в ядре орехов, выступает белок используемого сырья [58, 59].

Злоупотребление растительным молоком, имеющим в своем составе такие пищевые добавки, как камеди и каррагинан, может спровоцировать воспаление кишечника и даже СРК [60]. На примере миндального, рисового и бобового молока клинически подтверждено, что полный переход в питании на молоко растительного происхождения, особенно в детском возрасте, провоцирует патологию почек (в частности, для миндального молока характерно повышенное содержание оксалата кальция), приводит к нарушениям мочевыделительных процессов и выраженному дефициту белка, проявляющемуся в гипоальбуминемии, пищевой аллергии и дерматитах и сопровождающемуся плохим набором веса [6163].

\section{СПИСОК ЛИТЕРАТУРЫ}

1. Белковые ингредиенты: очередной виток роста (по данным Mordor Intelligence, Innova Market Insight) [Текст]. - Режим доступа: http://bake.ingredients.pro/news/editorial/belkovye_ing redienty_ocherednoy_vitok_rosta/.

2. Soy Protein Ingredients Market - Growth, Trends and Forecasts (2017-2022) // https://mordorintelligence.com/industry-reports/soy-protein-ingredients-market; Global Rice Protein Market - Growth, Trends and Forecasts (2018-2023) // https://mordorintelligence.com/industry-reports/rice-protein-market.

3. Отчёт по результатам проведения маркетингового исследования рынка белковых концентратов и текстурированных белковых веществ (код ТН ВЭД 2106) государств-членов Европейского союза [Текст]. - Режим доступа: http://www.crpp.ru/Belkovie.pdf.

4. Будько, Д. Мировой рынок альтернативных молочных продуктов: ожидается стремительный рост / Д. Будько // Бизнес пищевых ингредиентов. Апрель-май 2016 [Текст]. - Режим доступа: https://novaprodukt.ru/ing/articles/non_dairy_milk/.

5. Settaluri, V.S. Peanuts and their nutritional aspects - a review / V.S. Settaluri, C.V.K. Kandala,
N. Puppala, J. Sundaram // Food and Nutrition Sciences. - 2012. - V. 3. - № 12. - P. 1644-1650, doi: 10.4236/fns.2012.312215.

6. Sethi, S. Plant-based milk alternatives an emerging segment of functional beverages: a review / S. Sethi, S.K. Tyagi, R.K. Anurag // Journal of Food Science and Technology. - 2016. - V. 53. - Iss. 9. - P. 3408-3423, doi:10.1007/s13197-016-2328-3.

7. Самофалова, Л.А. Научное обоснование применения прорастающих семян двудольных растений в производстве растительной основы и заменителей молочных продуктов функционального значения: автореф. дисс. ... д-ра техн. наук: 05.18.07 / Л.А. Самофалова. - СПб., 2010 - 32 с.

8. Makinen, O.E. Foods for special dietary needs: non-dairy plant-based milk substitutes and fermented dairy-type products / O.E. Makinen, V. Wanhalinna, E. Zannini, E.K. Arendt // Critical Reviews in Food Science and Nutrition. - 2016. - V. 56 (3). - P. 339-49, doi:10.1080/10408398.2012.761950.

9. Granato, D. Functional foods and nondairy probiotic food development: trends, concepts, and products / D. Granato, G.F. Branco, F. Nazzaro, A.G. Cruz, J.A. Faria // Comprehensive Reviews in Food Science and Food Safety. - 2010. - V. 9. - № 3. P. 292-302, doi: 10.1111/j.1541-4337.2010.00110.x.

10. Min, M. Non-dairy probiotic food products: An emerging group of functional foods / M. Min, C.R. Bunt, S.L. Mason, M.A. Hussain // Critical Reviews in Food Science and Nutrition. - 2018. - V. 58. - P. 1-16, doi: 10.1080/10408398.2018.1462760.

11. Hambleton, M. Us non-dairy milk market report / M. Hambleton [Текст]. - Режим доступа: // https://store.mintel.com/US-NON-DAIRY-MILK-MARKET-REPORT.

12. Как развивается рынок растительных аналогов молока? // Milknews: Новости и аналитика молочного рынка. - 03.05.2018.

13. Wong, V. Soy milk fades as americans opt for drinkable almonds / V. Wong // Business Week. 22.08.2013.

14. Kolapo, A.L. Production and quality evaluation of soy-corn milk / A.L. Kolapo, G.R. Oladimeji // Journal of Applied Biosciences. - 2008. - V.1 (2). P. 40-45.

15. Jiang, S. Food quality improvement of soy milk made from short-time germinated soybeans / S. Jiang, W. Cai, B. Xu // Foods. - 2013. - V. 2. P. 198-212, https://doi.org/10.3390/foods2020198.

16. Udeozor, L.O. Tigernut-soy milk drink: preparation, proximate composition and sensory qualities / L.O. Udeozor // International Journal of Food and Nutrition Science. - 2012. - V. 1. - № 4. - P. 18-26.

17. Alozie, Y.E. Nutritional and sensory properties of almond (Prunus amygdalu Var. Dulcis) seed milk / Y.E. Alozie, U.S. Udofia // World Journal of Dairy \& Food Sciences. - 2015. - V. 10 (2). - P. 117-121, doi: 10.5829/idosi.wjdfs.2015.10.2.9622.

18. Zahra, A.K. Influence of processing conditions on the physicochemical and sensory properties of sesame milk: a novel nutritional beverage / A.K. Zahra, M. Varidi, M.J. Varidi, H. Pourazarang // LWT - Food Science and Technology. - 2014. - V. 57. - Iss. 1. - P. 299-305, doi.org/10.1016/j.Iwt.2013.12.028. 
19. Diarra, K. Peanut milk and peanut milk based products production: a review / K. Diarra, G.N. Zhang, J. Chen // Critical Reviews in Food Science and Nutrition. - 2005. - V. 45 (5). - P. 405-423, doi.org/10.1080/10408390590967685.

20. Bastıoğlu, A.Z. Spray dried melon seed milk powder: physical, rheological and sensory properties / A.Z. Bastıoğlu, D. Tomruk, M. Koç, F.K. Ertekin // Journal of Food Science and Technology. - 2016. - V. 53 (5). - P. 2396-2404, doi.org/10.1007/s13197-0162214-z.

21. Plant-based milk alternatives // Food Standards Australia New Zealand. - June 2016.

22. Okorie, S.U. Effect of blending and storage conditions on the microbial quality and sensory characteristics of soy-tiger nut milk beverage / S.U. Okorie, I.I. Adedokun, N.H. Duru // Food Science and Quality Management. - 2014. - V. 31. - P. 96-103.

23. Functional and luxury foods market analysis: Market Analysis - Functional Foods // Frost \& Sullivan. November 2015.

24. Dharmasena, S. Unraveling demand for dairy-alternative beverages in the United States: The case of soymilk / S. Dharmasena, O. Capps // Agricultural and Resource Economics Review. - 2014. V. 43. - Iss. 1. - P. 140-157.

25. Sánchez-Zapata, E. Tiger Nut (Cyperus esculentus) commercialization: health aspects, composition, properties, and food applications / E. Sánchez-Zapata, J. Fernández-López, J. Angel Pérez-Alvarez // Comprehensive Reviews in Food Science and Food Safety. - 2012. - V. 11. - № 4. - P. 366-377, doi: 10.1111/j.1541-4337.2012.00190.x.

26. Пат. РФ № 2421006, A23C 11/10, A23L 1/20. Способ получения соевого молока из соевой муки и его применение / М. Янагисава, Т. Косеки, А. Иура, Т. Нисимура (Япония). - № 2008142540/13; заявл. 27.03.2007; опубл. 20.06.2011. - Бюл. № 17.

27. Briviba, K. Ultra high pressure homogenisation of almond milk: physico-chemical and physiological effects / K. Briviba, V. Gräf, E. Walz, B. Guamis, P. Butz // Food Chemistry. - 2015. - V. 192. - P. 82-89, doi: 10.1016/j.foodchem.2015.06.063.

28. Dhakal, S. Effect of high pressure processing on the immunoreactivity of almond milk / S. Dhakal, Ch. Liu, Yi. Zhang et al. // Food Research International. 2014. - V. 62. - P. 215-222, doi: 10.1002/jsfa.7576.

29. Valencia-Flores, D.C. Comparing the effects of ultra-high-pressure homogenization and conventional thermal treatments on the microbiological, physical, and chemical quality of almond beverages / D.C. Valencia-Flores, M. Hernández-Herrero, B. Guamis, V. Ferragut // Journal of Food Science. - 2013. - V. 78. Iss. 2. - P. E199-E205, doi.org/10.1111/17503841.12029.

30. Maghsoudlou, Ya. Optimization of ultrasound-assisted stabilization and formulation of almond milk / Ya. Maghsoudlou, M. Alami, M. Mashkour, M.H. Shahraki // Journal of Food Processing and Preservation. - 2016. - V. 40. - № 5. - P. 828-839, doi: $10.1111 /$ jpp. 12661 .

31. Iswarin, S.J. Coconut milk's fat breaking by means of ultrasound / S.J. Iswarin, B. Permadi // International Journal of Basic \& Applied Sciences. - 2012.
- V. 12. - № 1. - P. 1-5.

32. Патент 2448530 РФ. A23L 1/30, A23L 1/36. Способ получения кедрового молочка, многофункционального профилактического продукта питания I А.А. Кущин, Д.А. Кущин (Россия). № 2010116977/13, Заявл. 29.04.2010; Опубл. 27.04.2012, Бюл. № 12.

33. Egorova, E.Ju. Production of vegetable "milk" from oilcakes using ultrasonic cavitation / E.Ju. Egorova, V.N. Khmelev, Ju.V. Morozhenko, I.Ju. Reznichenko // Foods and Raw Materials. - 2017. - V. 5. № 2. - P. 24-35, doi: 10.21603/2308-4057-2017-2-2435.

34. Mäkinen, O.E. Physicochemical and acid gelation properties of commercial UHT-treated plantbased milk substitutes and lactose free bovine milk / O.E. Mäkinen, T. Uniacke-Lowe, J.A. O'Mahony, E.K. Arendt // Food Chemistry. - 2015. - V. 168. P. 630-638, doi: 10.1016/j.foodchem.2014.07.036.

35. Jeske, S. Evaluation of physicochemical and glycaemic properties of commercial plant-based milk substitutes / S. Jeske, E. Zannini, E.K. Arendt // Plant Foods for Human Nutrition. - 2017. - V. 72. - Iss. 1. P. 26-33, doi: 10.1007/s11130-016-0583-0.

36. Самофалова, Л.А. Анализ фризико-химических основ технологии растительных заменителей молока / Л.А. Самофалова, О.В. Сафронова // Технология и товароведение инновационных пищевых продуктов. - 2016. - № 2 (37). - С. 60-64.

37. Аникеева, Н.В. Вопросы биотехнологий белковых препаратов в условиях продовольственного кризиса / Н.В. Аникеева // Вестник Алтайского государственного аграрного университета. - 2010. - № 4 (66). - С. 91-95.

38. Акимова, О.В. Физиолого-биохимические особенности формирования продуктивности и качества зерна голозерных и пленчатых сортов овса в условиях южной лесостепи Западной Сибири: автореф. дис. ... к.с.-Х.н.: 06.01 .09 / О.В. Акимова. - Тюмень, 2008. - 16 c.

39. Алешин, Е.П. Рис: Монография / Е.П. Алешин, Н.Е. Алешин. - Краснодар: Рис России, 1997. $-504 \mathrm{c}$.

40. Шаззо, А.А. Продукты переработки рисазерна в диетическом питании / А.А. Шаззо, А.П. Гюлушанян, Е.П. Корнена [и др.] // Новые технологии. -2011 . - № 3. - С. 72-75.

41. Тупольских, Т.И. Анализ влияния химических способов замачивания зерна кукурузы на растворимость белков / Т.И. Тупольских, Т.А. Вифлянцева // Молодой исследователь Дона. - 2018. - № 2 (11). - С. 102-106.

42. Миневич, И.Э. Разработка технологических решений переработки семян льна для создания функциональных пищевых продуктов: автореф. дис. ... к.Т.н.: 05.18.01 / И.Э. Миневич. - М., 2009. $27 \mathrm{c.}$

43. Чернов, А.И. Особенности белков амаранта (Amaranthus L.): экстракция, свойства, использование / А.И. Чернов, Ю.А. Куликов, Г.А. Гасимова // Нетрадиционные природные ресурсы, инновационные технологии и продукты: РАЕН. - М., 2005. - Вып. 12. - С. 70-81. 


\section{Е. Ю. ЕГОРОВА}

44. Васильева, А.Г. Химический состав и потенциальная биологическая ценность семян тыквы различных сортов / А.Г. Васильева, И.А. Круглова // Известия вузов. Пищевая технология. - 2007. - № 5-6. - С. 30-33.

45. Пыжов, В.Х. Состав и метаболические изменения белков и жирного масла семян миндаля: автореф. дис. ... к.б.н.: 03.00.04 / В.Х. Пыжов. - М., 1973. - $18 \mathrm{C}$.

46. Анточий, О.В. Биохимическая характеристика липидно-белкового комплекса плодов грецкого ореха и лещины и разработка функциональных пищевых продуктов на их основе: автореф. дис. ... К.Т.н.: 03.00.04, 05.18.06 / О.В. Анточий. - Краснодар, 2004. - 24 c.

47. Yuan, S. Elimination of trypsin inhibitor activity and beany flavor in soy milk by consecutive blanching and ultrahigh-temperature (UHT) processing / S. Yuan, S.K.C. Chang, Z. Liu, B. Xu // Journal of Agricultural and Food Chemistry. - 2008. - V. 56 (17). P. 7957-7963, doi:10.1021/jf801039h.

48. Deswal, A. Optimization of enzymatic production process of oat milk using response surface methodology / A. Deswal, N.S. Deora, H.N. Mishra // Food and Bioprocess Technology. - 2014. - V. 7 (2). - P. 610-618, doi.org/10.1007/s11947-013-1144-2.

49. Rajan, A. Production of soya milk containing low flatulence-causing oligosaccharides in a packed bed reactor using immobilised a-galactosidase: Immobilised a-galactosidase / A. Rajan, G.R. Nair // International Journal of Food Science \& Technology. - 2010. - V. 45. - № 10. - P. 2023-2031, doi:10.1111/j.13652621.2010.02354.x.

50. Ikya, J.K. Effect of cooking temperature on some quality characteristics of soy milk / J.K. Ikya, D.I. Gernah, H.E. Ojobo, O.K. Oni // Journal of Food Science and Technology. - 2013. - V. 5 (5). - P. $543-$ 546, doi:10.19026/ajfst.5.3123.

51. Zhang, H. High-pressure effects on proteins in soy milk / H. Zhang, L. Li, E. Tatsumi, S. Isobe // LWT - Food Science and Technology. - 2005. - V. 38. - P. 7-14.

52. Council Regulation (EC) № 1234/2007 of 22 October 2007. Establishing a common organisation of agricultural markets and on specific provisions for certain agricultural products (Single CMO Regulation) // Official Journal of the European Union. - 16.11.2007. P. 34.

53. Das, A. Cereal based functional food of Indian subcontinent: a review / A. Das, U. Raychaudhuri, R. Chakraborty // Journal of Food Science and Technology. - 2012. - V. 49 (6). - P. 665-672, doi: 10.1007/s13197-011-0474-1.

54. Анисимова, Л.В. Стойкость при хранении овсяной муки, полученной разными способами / Л.В. Анисимова, О.И.А. Солтан // Ползуновский вестник. - 2017. - № 4. - С. 14-20.

55. Нициевская, К.Н. Исследование технических показателей семян льна белого и коричневого для применения в пищевой промышленности / К.Н. Нициевская, Г.П. Чекрыга, О.К. Мотовилов // Ползуновский вестник. - 2018. - № 1. - С. 49-53, doi: 10.25712/ASTU.2072-8921.2018.01.010.

56. Afolabi, I.S. Production of a new plant-based milk from Adenanthera pavonina seed and evaluation of Its nutritional and health benefit / I.S. Afolabi, Ch. Nwachukwu, Ch.S. Ezeoke et al. // Frontiers in Nutrition. - 2018. - V. 5, doi: 10.3389/fnut.2018.00009.

57. Шейбак, В.М. Аргинин и иммунная система - возможные механизмы взаимодействия / В.М. Шейбак, А.Ю. Павлюковец // Вестник ВГМУ. - 2013. - T. 12. - № 1. - C. 6-13.

58. Capriotti, A.L. Protein profile of mature soybean seeds and prepared soybean milk / A.L. Capriotti, G. Caruso, C. Cavaliere et al. // Journal of Agricultural and Food Chemistry. - 2014. - V. 62 (40). - P. 98939899, doi:10.1021/jf5034152.

59. Cabanillas, B. Allergic reactions to pine nut: a review / B. Cabanillas, N. Novak // Journal of Investigational Allergology and Clinical Immunology. - 2015. V. 25 (5). - P. 329-333.

60. McClees, H. 10 Types of non-dairy milk you can make at home / $\mathrm{H}$. McClees // The Alternative Daily. - 2016. - 16 January.

61. Ellis, D. Hyperoxaluria and genitourinary disorders in children ingesting almond milk products / D. Ellis, J. Lieb // Journal of Pediatrics. - 2015. V. 167 (5). $\quad-\quad$ P. 1155-1158, doi: 10.1016/j.jpeds.2015.08.029

62. Mori, F. A kwashiorkor case due to the use of an exclusive rice milk diet to treat atopic dermatitis / F. Mori, D. Serranti, S. Barni et al. // Nutrition Journal. 2015. - V. 14 (1). - P. 83-84, doi: 10.1186/s12937015-0071-7.

63. Бушуева, Т.В. Соя и ее роль в питании детей / Т.В. Бушуева, Т.Э. Боровик, Т.Н. Степанова, Н.Н. Семенова // Вопросы современной педиатрии. - 2011. - № 1. - C. 77-82.

Егорова Елена Юрьевна, д.т.н., профрессор кафедры технологии хранения и переработки зерна ФГБОУ ВО «Алтайский государственный технический университет им. И.И. Ползунова», 656038, . Барнаул, ул. Ленина, 46, e-mail: egorovaeyu@mail.ru, тел.: (3852) 29-07-55. 